\title{
THE RESERVES AND SANCTUARIES OF CEYLON
}

\author{
By A. M. MongaN-Davies
}

With the annual increase in the population and the ever decpening human advance into the remoter areas of Ceylon, it has become recognized that the ultimate extermination of the larger fauna of the country is alarmingly close at hand. In fact, only in those reserves that survive the innumerable demands of a rapidly growing country will future generations of Ceylon be able to see their natural heritage in its wild state.

Ceylon's reserves have a total aren of 1,728 sq. miles, or 6.28 per cent of the area of the island. They are under the management of the Wild Life Department and consist of twenty-five Sanctuaries, four strict Natural Reserves, six Intermediate Zones and three National Parks. They include all types of plant association and climatic condition from the dry, low-country zone savannah or "damana" forest, with its shallow saline soil and long periods of drought, to the wet upcountry zone " patana" and stunted forest with its low temperatures and annual rainfall of over 100 inches. They contain representatives of all the fauna of the island.

The Sanctuaries.-These are areas, which may include private or state lands, where all forms of human occupation is permitted; other than the hunting, killing or capturing of birds and animals. They are the breeding grounds of storks, herons, egrets, pelicans, cormorants, ibis and many other aquatic birds, both resident and migratory. Flamingos, grey partridge and many other rare birds are also to be found in these sanctunries.

The Strict Natural Reserves.-These are areas in which the fauna and flora or other objects of aesthetic, gcological, prehistorical, archæological or historical interest are left completely undisturbed as far as possible. Public entry into any of these areas is prohibited except for scientific resenrch. They comprise an area of 234 sq. miles. 'The two smallest of these areas are IIakgala in the central hills and Ritigala in the lowcountry; both of these are more or less flora reserves but do contain a small amount of wild life. 'The Yala strict natural reserve is situated in the south-east corner of the island and consists mainly of high damana forest interspaced with large outcrops of rock and small hills. This rescrve holds a fair number of elephant, bear, sambar and buffalo, but owing to the lack of funds for the construction and repairs of tanks and water holes, many animals migrate during the annual drought 
to the two boundary rivers on the east and west of the reserve. Wasgomuwa, the fourth of the strict natural reserves, although large in area (112 sq. miles) has not the same wealth of wild life as the other parks and reserves. Poaching has always been a problem there, owing to the lack of roads and the wild nature of the country. Spotted deer, and to a lesser extent sambar, pig and buffalo are present, but elephant are seldom seen.

The Intermediate Zones.-Although neither sanctuaries nor strict natural reserves, the intermediate zones form an integral part in the scheme of wild life preservation. 'They are, for the most part, areas adjacent to strict natural reserves and national parks, where controlled shooting is permitted during certain months of the year. They serve as buffer zones to civilization and migration zones for animals. During the months that shooting is prohibited the intermediate zones are, in effect, national parks. .

The National Parlis.-In comparison with many other countries the total aren of 410 sq. miles of national parks may not be great, but what is wanting in area is partly compensated for by the number and varicty of animals these parks contain. In fact, Ceylon can be proud of having two of the best national parks in Asia, Ruhuna in the south-east and Wilpattu in the north-west. 'The Gal Oya Valley national park is a recent addition and the only reserve not controlled by the Wild Life Department.

Although at opposite ends of the island, the vegetation and climatic conditions of Ruhuna and Wilpattu are very similar and both contain stands of high forest and scrub jungle diversificd with areas of parkland, low hills and rocky outerops. Both parks receive their principal rainfall with the north-cast monsoon between October and $\Lambda$ pril, but are afterwards subject to a period of drought that is sometimes alarmingly severe. In 1953, for example, a large number of sambar and buffalo were found dead in Wilpattu and the heat was so intense that spotted deer were seen returning to drink sometimes as often as three times a day. Others drank saline water from some of the "villus"* or ate various kinds of bark and leaves having a high water content.

\section{'Ine Animals of Ruiruna and Wilpattu}

Elephant.-'They are found in both parks. Small herds are sometimes secn in Ruhuna but the majority are lone

* "Villu" is the Sinhalese name for a marsh or small lake having cither fresh or salt water or a mixture of both. 


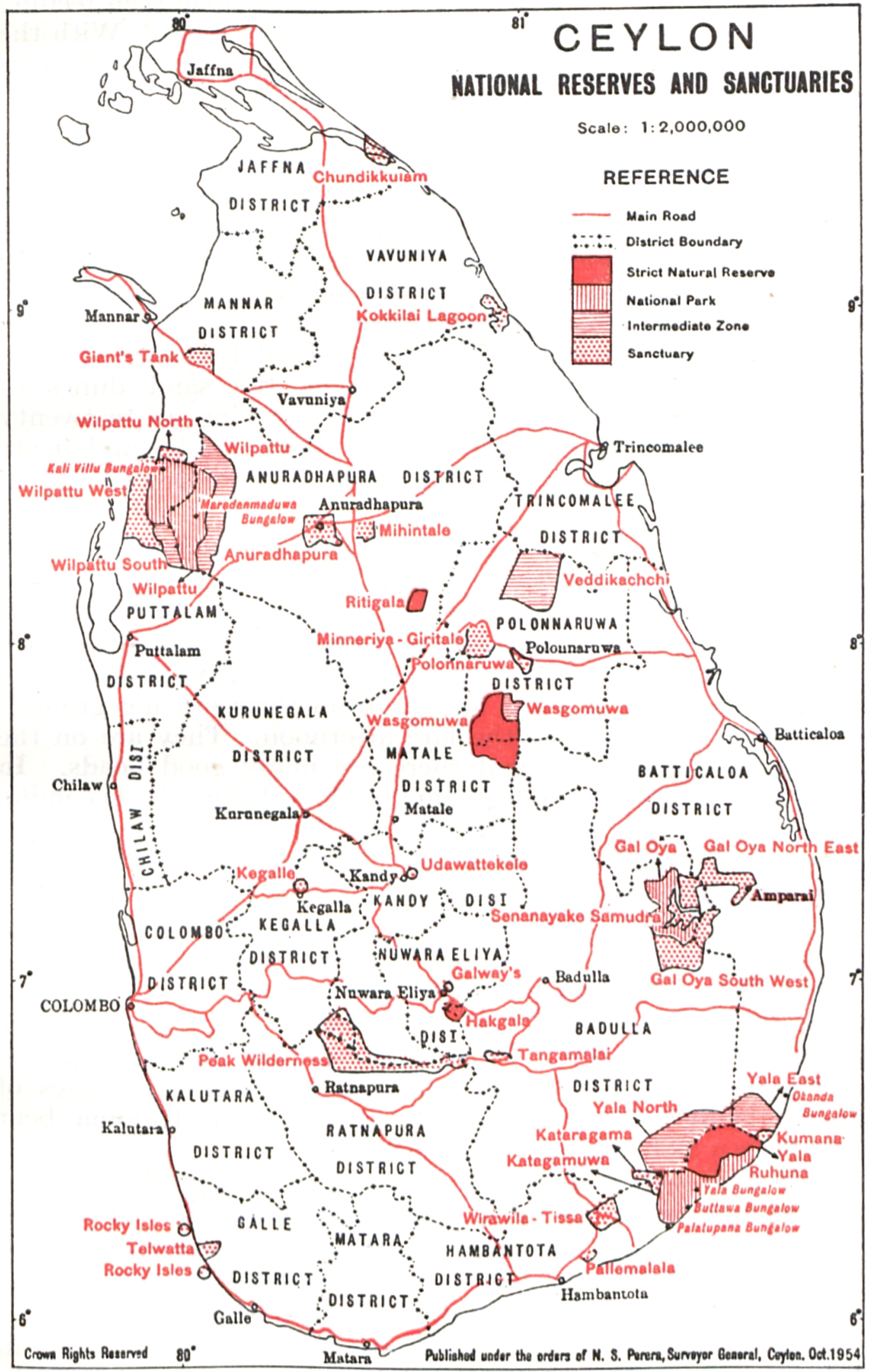


bulls. During the dry weather they are frequently seen feeding at any time of day in the open parks and tank edges. With the onset of the monsoon rains they return to feed in the forest areas and are then not so visible. -Tuskers have been seen in both parks but are very uncommon.

Buffalo.-This animal is common in both parks and is to be scen in numbers throughout the day either alone or in herds. In Ruhuna they are very susceptible to rinderpest and also to foot and mouth disease, which is brought into the park by stray cattle from villages outside it-a most serious problem that cannot, under present legislation, be overcome.

Sambar.-This handsome but shy animal is not often seen outside certain favoured localities, like the sand dunes of Patanagala in Ruhuna, where herds of anything up to twenty or more can sometimes be observed. Unfortunately sambar are very susceptible to drought and many have thus been lost in Wilpattu.

Spotted Decr.-This is the most common ungulate in Ceylon and is well distributed throughout Wilpattu and Ruhuna. In the former park herds of over a hundred animals can sometimes be seen grazing in the open parklands and tank edges in the early mornings. During the heat of the day they retire to the shade of some large tree or bush not far from their grazing grounds and emerge again during the late afternoon. 'They are on the increase in the reserves and there are many good heads. In Ruhuna the problem of grazing and watering is becoming increasingly acute especially during the periods of drought when the spotted deer find it hard to compete with the semiwild stray cattle and buffaloes.

Leopard.-This animal is seldom scen by visitors owing to its shy and nocturnal habits and the nature of the undergrowth.

Sloth Bear.-C'These animals are not uncommon in Wilpattu where they are well distributed and have been seen in family parties of threc or four. It is estimated that there is approximately one bear per square mile and many are the cases of rangers being attacked by these animals. In Ruhuna bear are not scen as frequently as in Wilpattu.

Wild Boar.-This animal is common in both parks and can be seen rooting in the open plains and tank sides during the carly mornings and evenings, sometimes in large sounders of over thirty. During the hot hours of the day they retire to the seclusion of some thick patch of scrub or muddy water holc.

Peafowl.-These clegant birds are remarkably common in Ruhuna; so much so that a population " crash " is not improb- 


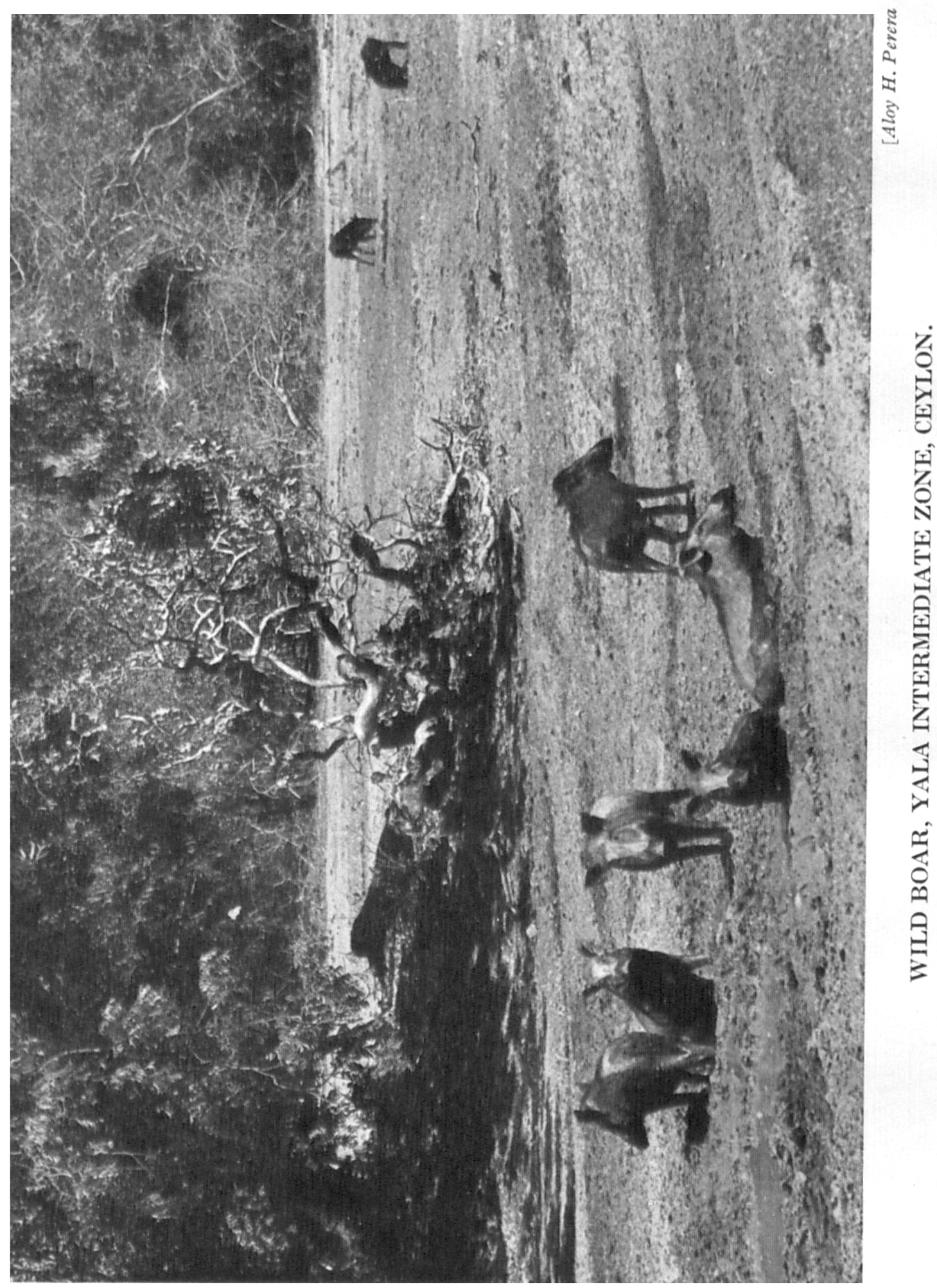


able; they are to be seen at all times of the day. In Wilpattu they are not so plentiful.

It is quite impossible to make an accurate count of the animals in the parks and reserves but the Department of Wild Life does occasionally publish estimated population figures of the larger fauna in the national parks. The following table has been compiled with the assistance of the annunl reports of the warden and represents the position in Ruhuna and Wilpattu national parks at the end of 1954.

\begin{tabular}{ll|l|c|c}
\hline & & $\begin{array}{c}\text { Ruhunn } \\
\text { National } \\
\text { Park, } \\
\text { 91 sq. miles }\end{array}$ & $\begin{array}{c}\text { IVilpattu } \\
\text { National } \\
\text { Park, } \\
\text { 212 sq. miles }\end{array}$ \\
\hline Elephant $\cdot$ & $\cdot$ & $\cdot$ & 75 & 50 \\
\hline Buffalo $\cdot$ & $\cdot$ & $\cdot$ & 500 & 200 \\
\hline Sambar & $\cdot$ & $\cdot$ & 200 & 400 \\
\hline Spotted Deer & $\cdot$ & $\cdot$ & 1,500 & 3,000 \\
\hline Leopard & $\cdot$ & $\cdot$ & 50 & 75 \\
\hline Sloth Bear & $\cdot$ & $\cdot$ & 75 & 300 \\
\hline Wild Boar & $\cdot$ & $\cdot$ & 800 & 700 \\
\hline Peafowl & $\cdot$ & $\cdot$ & 500 & 200 \\
\hline
\end{tabular}

The Future.-Ceylon is justifiably proud of her reserves and national parks. Yet it is undeniable that their very existence is threatened day by day. 'This will continue until they are vested in a National Trust or similar body administered by a Board of Trustees with autonomous control. Nature has given the island a wealth of wild life. If once this is lost no-amount of preservation or legislation will bring it back. 